\title{
Sensitivity of Multiresistant Bacteria and Methicillin-Resistant Staphylococcus aureus to ethanolic root extract of Raphanus sativus
}

\author{
Dejan Stojković ${ }^{1}$, Marija Smiljković ${ }^{1}$, Miloš Nikolić ${ }^{1}$, Jelena Živković2,*, AND MARINA \\ SOKović ${ }^{1}$ \\ ${ }^{1}$ Department of Plant Physiology, Institute for Biological Research "Siniša Stanković", University of Belgrade, Bulevar Despota Stefana 142, 11000 \\ Belgrade, Serbia \\ ${ }^{2}$ Institute for Medicinal Plant Research "Dr. Josif Pančić", Tadeuša Košćuška 1, 11000 Belgrade, Serbia \\ *Corresponding author: jzivkovic@mocbilja.rs
}

Received: October 11, 2018

Accepted: December 16, 2018

Published on-line: December 20, 2018

Published: December 25, 2018

\begin{abstract}
Raphanus sativus L. (Brassicaceae) is an edible plant, whose root is consumed all over the world. The objective of this study was to test antibacterial potential of $R$. sativus ethanolic extract on 12 pathogenic bacteria including multiresistant bacterial strains and MRSA. All of the tested bacteria showed sensitivity to the antibacterial effect of $R$. sativus ethanolic extract with minimum inhibitory (MIC) and minimum bactericidal concentrations (MBC) in range of $15 \mu \mathrm{g} / \mathrm{mL}-500 \mu \mathrm{g} / \mathrm{mL}$. It is interesting to note that Raphanus extract showed the highest activity against multiresistant strain of Pseudomonas aeruginosa with equal inhibitory and bactericidal concentrations of $15 \mu \mathrm{g} / \mathrm{mL}$, while the most resistant strain to the effect of the extract was Proteus mirabilis (MIC and MBC of the extract were $300 \mu \mathrm{g} / \mathrm{mL}$ and $500 \mu \mathrm{g} / \mathrm{mL}$, respectively). In disk diffusion assay, zones of inhibitions were measured ranging from $8 \mathrm{~mm}$ to $22 \mathrm{~mm}$.
\end{abstract}

Key words: Raphanus sativus; ethanolic extract; antibacterial; multiresistant; methicillin-resistant

http://dx.doi.org/10.5937/leksir1838035S

\section{INTRODUCTION}

Radish, the most common vegetable in the Brassicaceae family, is an edible root cultivated and consumed worldwide (Mithen et al., 2010). The most common radish cultivars are the wellknown red varieties, while other varieties vary in size, color and cultivation requirements (Gutierrez and Perez, 2004; Hara et al., 2009). Radish has been used for food since prehistoric times. It was grown for its seed oil in Ancient Egypt, while some radish cultivars are grown for their leaves used as fodder (Al-Shehbaz, 1985; Davidson, 2014; Huxley et al., 1992; Mabberley, 2008). Besides being a food crop, radish also has various medicinal actions. It has been used in Estonian ethnopharmacology for relief of tumor symptoms (Sak et al., 2014), in India for issues like urinary problems and piles (Ahmad and Beg 2001) while in Mexican traditional medicine black radish roots are used for the treatment of cholesterol gallstones, and for decreasing serum lipid levels (Castro-Torres et al., 2012). It has potential for probiotic usage due to the presence of lactic acid bacterial strains such as Lactobacillus plantarum and Lactobacillus fermentum which could be isolated from fermented radishes (Damodharan et al., 2015). The roots stimulate appetite and digestion, having a tonic and laxative effect upon the intestines and indirectly stimulating the flow of bile (Chevallier 1996). The leaves, seeds and old roots are used in the treatment of asthma and other chest complaints (Duke and Ayensu, 1985). This paper studies growth inhibition of multiresistant bacteria and methicilin-resistant Staphylococcus aureus by Raphanus sativus root ethanolic extract. Multiresistance is antimicrobial resistance shown by a species of microorganism to multiple antimicrobial drugs. Some of multiresistant bacteria besides mentioned are: Proteus mirabilis, Pseudomonas aeruginosa and Escherichia coli. Proteus mirabilis is a gram-negative, facultative anaerobic, rod-shaped bacterium. It causes $90 \%$ of all Proteus infections in human. It is widely distributed in soil and water. Pseudomonas aeruginosa is a gram-negative rod-shaped bacterium that can cause severe infections, especially in critically ill and immunocompromised patients (Bassetti et al., 2018). Escherichia coli is a gram-negative, facultative anaerobic, rodshaped bacterium that is commonly found in the lower intestine of warm-blooded organisms. Methicillin-resistant Staphylococcus aureus (MRSA) is a bacterium responsible for several difficult-to-treat infections in humans. MRSA is any strain of Staphylococcus aureus that has developed multi-resistance to beta-lactam antibiotics, which include the penicillins and the 
cephalosporins (Stapleton and Taylor, 2002).

\section{MATERIALS AND METHODS}

\subsection{Sample collection and extract preparation}

$R$. sativus (white variety of radish) was purchased from local supermarket, lyophilized and smashed to a fine powder, prior to extraction with ethanol. The powdered root of $R$. sativus sample $(\sim 10 \mathrm{~g})$ was extracted by stirring with $300 \mathrm{~mL}$ of ethanol, at room temperature, $150 \mathrm{rpm}$, for $24 \mathrm{~h}$. The extract was filtered through Whatman No. 4 paper. The residue was then re-extracted twice with additional portions $(300 \mathrm{~mL})$ of ethanol. The combined extracts were evaporated at $35^{\circ} \mathrm{C}$ (rotary evaporator Büchi R-210, Flawil, Switzerland) to remove ethanol.

\subsection{Microorganisms}

The Gram-positive bacteria Staphylococcus aureus (ATCC 6538), Staphylococcus aureus (MRSA strain), Bacillus cereus (clinical isolate), Micrococcus flavus (ATCC 10240) and Listeria monocytogenes (NCTC 7973); as well as Gram-negative bacteria Pseudomonas aeruginosa (ATCC 27853), Salmonella typhimurium (ATCC 13311), Escherichia coli (ATCC 35210), Proteus mirabilis and Enterobacter cloacae (human isolate), as well as multiresistant strains (MR) of Escherichia coli and Pseudomonas aeruginosa were used. Isolation and determination of clinical bacteria used in this study was previously described in our study (Kartsev et al., 2018).

\subsubsection{Microdilution method}

The antibacterial assay was carried out by a microdilution method (CLSI, 2009). The bacterial suspensions were adjusted with sterile saline to a concentration of $1.0 \times 10^{5} \mathrm{CFU} / \mathrm{mL}$. Ethanolic extract was dissolved in 5\% DMSO solution containing $0.1 \%$ Tween $80(\mathrm{v} / \mathrm{v})(10 \mathrm{mg} / \mathrm{mL})$ and added in Tryptic Soy broth (TSB) medium $(100 \mu \mathrm{L})$ with bacterial inoculum $\left(1.0 \times 10^{4} \mathrm{CFU}\right.$ per well). The lowest concentrations without visible growth (at the binocular microscope) were defined as concentrations that completely inhibited bacterial growth (MICs). The MICs obtained from the susceptibility testing of various bacteria to tested extracts were determined also by a colorimetric microbial viability assay based on reduction of an INT ((p-iodonitrotetrazolium violet) [2-(4-iodophenyl)3-(4-nitrphenyl)-5-phenyltetrazolium chloride; Sigma]) color and compared with positive control for each bacterial strain The MBCs were determined by serial sub-cultivation of $2 \mu \mathrm{L}$ into microtitre plates containing $100 \mu \mathrm{L}$ of broth per well and further incubation for $24 \mathrm{~h}$. The lowest concentration with no visible growth was defined as the MBC, indicating $99.5 \%$ killing of the original inoculum. The optical density of each well was measured at a wavelength of $655 \mathrm{~nm}$ by Microplate manager 4.0 (Bio-Rad Laboratories) and compared with a blank (broth medium plus diluted extracts) and the positive control. Ampicillin (Panfarma, Belgrade, Serbia) was used as positive control ( $1 \mathrm{mg} / \mathrm{mL}$ in sterile physiological saline). Five percent DMSO was used as a negative control.

\subsubsection{Disc-diffusion assay}

Antibacterial activity of the extract was also determined using filter paper disc diffusion assay (Sokovic et al., 2008). Inoculums of the test bacteria were prepared equivalent to McFarland Standard 0.5. Uniform bacterial lawns were made using $100 \mu \mathrm{L}$ inoculums on a nutrient agar plate. Filter paper (Whatman) discs $(5.0 \mathrm{~mm})$ soaked with test extract were placed over seeded plates. The plates were incubated at $37^{\circ} \mathrm{C}$ for $24 \mathrm{~h}$ Activity was measured in terms of zone of inhibition ( $\mathrm{mm}$ ) The net zone of inhibition was determined by subtracting the disc diameter (i.e. $5.0 \mathrm{~mm}$ ) from the total zone of inhibition shown by the test disc in terms of clear zone around the disc.
Ampicillin (Panfarma, Belgrade, Serbia) was used as positive control (1 $\mathrm{mg} / \mathrm{mL}$ in sterile physiological saline). Five percent DMSO was used as a negative control.

Table 1. Minimum inhibitory (MIC) and minimum bactericidal concentrations (MBC) of Raphanus sativus root ethanolic extract in $\mathrm{mg} / \mathrm{mL}$

\begin{tabular}{|c|c|c|c|}
\hline Bacteria & & $\begin{array}{r}\text { R. sativus } \\
\text { extract }\end{array}$ & Ampicillin \\
\hline \multirow[t]{2}{*}{ S. aureus } & MIC & 0.15 & 0.74 \\
\hline & MBC & 0.15 & 1.24 \\
\hline \multirow[t]{2}{*}{ S. aureus (MRSA) } & MIC & 0.1 & $>1.50$ \\
\hline & MBC & 0.15 & $>1.50$ \\
\hline \multirow[t]{2}{*}{ B. cereus } & MIC & 0.05 & 0.25 \\
\hline & MBC & 0.05 & 0.37 \\
\hline \multirow[t]{2}{*}{ M. flavus } & MIC & 0.05 & 0.49 \\
\hline & MBC & 0.075 & 0.74 \\
\hline \multirow[t]{2}{*}{ L. monocytogenes } & MIC & 0.1 & 0.37 \\
\hline & $\mathrm{MBC}$ & 0.15 & 0.49 \\
\hline \multirow[t]{2}{*}{ P. aeruginosa } & MIC & 0.2 & 0.25 \\
\hline & MBC & 0.2 & 0.37 \\
\hline \multirow[t]{2}{*}{ S. typhimurium } & MIC & 0.25 & 0.25 \\
\hline & MBC & 0.3 & 0.37 \\
\hline \multirow[t]{2}{*}{ E. coli } & MIC & 0.25 & 0.37 \\
\hline & MBC & 0.3 & 0.37 \\
\hline \multirow[t]{2}{*}{ E. cloacae } & MIC & 0.3 & 0.49 \\
\hline & MBC & 0.4 & 0.74 \\
\hline \multirow[t]{2}{*}{ P. mirabilis } & MIC & 0.3 & 0.74 \\
\hline & MBC & 0.5 & 0.74 \\
\hline \multirow[t]{2}{*}{ MR E. coli } & MIC & 0.05 & $>1.50$ \\
\hline & MBC & 0.05 & $>1.50$ \\
\hline \multirow[t]{2}{*}{ MR P. aeruginosa } & MIC & 0.015 & $>1.50$ \\
\hline & $\mathrm{MBC}$ & 0.015 & $>1.50$ \\
\hline
\end{tabular}

\section{RESULTS AND DISCUSSION}

The creation of drug-resistant pathogens has induced decline in the efficacy of traditional antimicrobial therapy. The resistance growth has been forced by prevalent use, and in some cases misuse, of antibacterial agents in treating a variety of infections (Spaulding et al., 2018). Previous studies reported good antimicrobial activity for Raphanus root (Gutierrez and Perez, 2004). Namely, juice obtained from root showed activity against Bacillus subtilis, Pseudomonas aeruginosa, and Salmonella typhi, while ethanolic and aqueous extracts showed activity against Streptococcus mutans and Candida albicans. In our study, all of the tested bacteria showed sensitivity to the $R$. sativus ethanolic extract with minimum inhibitory (MIC) and minimum bactericidal concentrations (MBC) ranging from 15 $\mu \mathrm{g} / \mathrm{mL}$ to $500 \mu \mathrm{g} / \mathrm{mL}$, tested by microdilution method (Table 1). Our results are better compared to previous results obtained by Ngoc et al. (2017) indicating higher activity. They showed that MIC values for Salmonela typhi and Pseudomonas aeruginosa were $40 \mathrm{mg} / \mathrm{mL}$, while for Bacillus cereus and Staphylococcus aureus were $20 \mathrm{mg} / \mathrm{mL}$. It is interesting to note that Raphanus extract showed the highest activity against multiresistant strain of Pseudomonas aeruginosa with equal inhibitory and bactericidal concentrations of $15 \mu \mathrm{g} / \mathrm{mL}$, while the most resistant strain to the effect of the extract was Proteus mirabilis (MIC and MBC of the extract were $300 \mu \mathrm{g} / \mathrm{mL}$ and $500 \mu \mathrm{g} / \mathrm{mL}$, respectively). The activity of the extract was slightly better 
towards Gram negative bacteria compared to Gram positive bacteria. These differences in the activity might be attributed to different composition of cell walls of Gram positive and Gram negative bacteria investigated in this study. The activity of commercial drug ampicillin was more or less uniform towards tested bacterial strains. In most of the cases it was lower compared to the activity of $R$. sativus root ethanolic extract (Table 1). In disk diffusion assay, zones of inhibitions were measured and were in the range of $8 \mathrm{~mm}-22 \mathrm{~mm}$ (Table 2). Again multiresistant $P$. aeruginosa was the most susceptible bacterium with inhibition zone of $22.0 \mathrm{~mm}$, followed by Staphylococcus aureus (MRSA strain) with the inhibition zone of $21.4 \mathrm{~mm}$. The most resistant was Proteus mirabilis with inhibition zone of $8.0 \mathrm{~mm}$. Antibacterial properties that are proven for different parts of radish, with the root as the most active, are positively correlated with level of isothyocyanate compounds (Beevi et al., 2009). Component found widely in radishes, 4-(methylthio)-3-butenyl isothiocyanate, has been proven to exhibit strong antimicrobial and antimutagenic activities (Nakamura et al., 2001). Also, plant contains raphanin, which can inhibit growth of Staphylococcus aureus, Escherichia coli, streptococci, pneumococci etc. (Yeung, 1985).

Table 2. Diameters of inhibition zones in disc diffusion assay

\begin{tabular}{lrr}
\hline Bacteria & $\begin{array}{r}\text { R. sativus } \\
\text { extract } \\
{[\mathrm{mm}]}\end{array}$ & $\begin{array}{r}\text { Ampicillin } \\
{[\mathrm{mm}]}\end{array}$ \\
\hline S. aureus & 18.2 & 18.1 \\
S. aureus (MRSA) & 21.4 & 17.2 \\
B. cereus & 19.6 & 18.5 \\
M. flavus & 15.8 & 16.4 \\
L. monocytogenes & 15.2 & 18.1 \\
P. aeruginosa & 14.4 & 16.3 \\
S. typhimurium & 12.2 & 14.6 \\
E. coli & 10.4 & 16.7 \\
E. cloacae & 14.9 & 18.6 \\
P. mirabilis & 8.0 & 10.3 \\
MR E. coli & 9.2 & 8.1 \\
MR P. aeruginosa & 22.0 & 8.3 \\
\hline
\end{tabular}

\section{CONCLUSION}

In summary the present study demonstrates good antibacterial activity of $R$. sativus ethanolic extract and is of importance for showing the effect towards strains of bacteria resistant to common therapeutic drugs, especially to Pseudomonas aeruginosa. It gives a baseline for researching Raphanus compounds involved in the exhibited antibacterial effect, identifying mechanisms of these compounds and also for further development of novel natural antibiotics.

\section{ACKNOWLEDGMENTS}

Acknowledgment. This work has been supported by the Serbian Ministry of Education, Science and Technological Development with financial support (Grant numbers OI173032, TR31089 and III46013).

\section{REFERENCES}

Al-Shehbaz, I. (1985). The genera of Brassiceae (Cruciferae; Brassicaceae) in the southeastern United States, Journal of the Arnold Arboretum. 66: 279-351.

Bassetti, M., Vena, A., Croxatto, A., Righi, E. and Guery, B. (2018). How to manage Pseudomonas aeruginosa infections, Drugs in Context 7: 212527.

Beevi, S. S., Mangamoori, L. N., Dhand, V. and Ramakrishna, D. S. (2009). Isothiocyanate Profile and Selective Antibacterial Activity of Root, Stem, and Leaf Extracts Derived from Raphanus sativus L., Foodborne Pathogens and Disease 6(1): 129-136.

Castro-Torres, I. G., Naranjo-Rodriguez, E. B., Ángel Dominguez-Ortiz, M., Gallegos-Estudillo, J. and SaavedraVelez, M. V. (2012). Antilithiasic and Hypolipidaemic Effects of Raphanus sativus L. var. niger on Mice Fed with a Lithogenic Diet, Journal of Biomedicine and Biotechnology 2012: $1-8$.

CLSI (2009). Methods for Dilution Antimicrobial Susceptibility Tests for Bacteria That Grow Aerobically, 11th Edition, Clinical and Laboratory Standards Institute, Wayne, USA.

Damodharan, K., Palaniyandi, S. A., Yang, S. H. and Suh, J.-W. (2015). In vitro probiotic characterization of Lactobacillus strains from fermented radish and their anti-adherence activity against enteric pathogens, Canadian Journal of Microbiology 61(11): 837-850.

Davidson, A. (2014). The Oxford Companion to Food, 3 edition edn, Oxford University Press, New York, NY.

Duke, J. A. and Ayensu, E. S. (1985). Medicinal plants of China, Reference Publications, Algonac, Mich. OCLC: 10558661.

Gutierrez, R. M. P. and Perez, R. L. (2004). Raphanus sativus (Radish): Their Chemistry and Biology, The Scientific World JOURNAL 4: 811-837.

Hara, M., Ito, F., Asai, T. and Kuboi, T. (2009). Variation in amylase activities in radish (Raphanus sativus) cultivars, Plant Foods for Human Nutrition (Dordrecht, Netherlands) 64(3): 188192.

Huxley, A., Griffiths, M. and Levy, M. (1992). The New Royal Horticultural Society dictionary of gardening. Volume 2, D-K, London : Macmillan.

Kartsev, V., Lichitsky, B., Geronikaki, A., Petrou, A., Smiljkovic, M., Kostic, M., Radanovic, O. and Sokovic, M. (2018). Design, synthesis and antimicrobial activity of usnic acid derivatives, MedChemComm 9(5): 870-882.

Mabberley, D. J. (2008). Mabberley's Plant-book: A Portable Dictionary of Plants, their Classification and Uses, 3 edition edn, Cambridge University Press, Cambridge, UK ; New York.

Mithen, R., Bennett, R. and Marquez, J. (2010). Glucosinolate biochemical diversity and innovation in the Brassicales, Phytochemistry 71(17-18): 2074-2086.

Nakamura, Y., Iwahashi, T., Tanaka, A., Koutani, J., Matsuo, T., Okamoto, S., Sato, K. and Ohtsuki, K. (2001). 4(Methylthio)-3-butenyl Isothiocyanate, a Principal Antimutagen in Daikon ( Raphanus sativus ; Japanese White Radish), Journal of Agricultural and Food Chemistry 49(12): 5755-5760. 
Ngoc, P. T. K., Nguyet, N. T. M. and Dao, D. T. A. (2017). Antimicrobial and antioxidant properties of the flavonoid extract from Raphanus sativus L., AIP Conference Proceedings 1878(1): 020026.

URL: https://aip.scitation.org/doi/abs/10.1063/1.5000194

Sak, K., Jurisoo, K. and Raal, A. (2014). Estonian folk traditional experiences on natural anticancer remedies: From past to the future, Pharmaceutical Biology 52(7): 855-866.

Sokovic, M. D., Glamoclija, J., Ciric, A., Grubišic, D., Stojkovic, D. and Ristic, M. (2008). Antimicrobial Activity of Essential Oils Isolated from Different Parts of Endemic Plant Portenschlagiella ramosissima Tutin, Journal of Essential Oil Research 20(4): 369-372.

Spaulding, C. N., Klein, R. D., Schreiber, H. L., Janetka, J. W. and Hultgren, S. J. (2018). Precision antimicrobial therapeutics: the path of least resistance?, npj Biofilms and Microbiomes 4(1): 4 .

Stapleton, P. D. and Taylor, P. W. (2002). Methicillin resistance in Staphylococcus aureus: mechanisms and modulation, Science Progress 85(1): 57-72.

Yeung, H. C. (1985). Handbook of Chinese Herbal Formulas, 2 edition edn, Redwing Book Co, Rosemead, CA. 